DOI 10.31558/2519-2949.2018.2.9

УДК $323.2: 327.7$

Михальська В. В., Донецький національний університет імені Василя Стуса

\title{
ПОСТКОНФЛІКТНІ УПРАВЛІНСЬКІ ПРАКТИКИ В ЕКОНОМІЧНІЙ ПОЛІТИЦІ
}

Стан економіки на постконфліктній території характеризується специффічними ознаками, обумовленими впливом минулого конфлікту. Саме иі ознаки дають змогу характеризувати управління постконфліктною територією як окрему політико-правову категорію. Вказана специфіка має обумовлювати діяльність акторів для досягнення мети постконфліктної політики.

У статті визначаються характеристики постконфліктних суспільних відносин, досліджуються проблеми функиіонування постконфліктної економіки та наводяться конкретні управлінські практики - приклади з різних постконфліктних країн світу, - які вирішують иі проблеми. Відновлення економіки постконфліктних територій розглянуто з позиції психологічного стану та потреб індивідів, які проживають на таких територіях. Виявлено, щяо рішення та дії в економічній політиці, орієнтовані на індивіда, можуть сприяти досягненню примирення в суспільстві та запобігти поверненню до стану конфлікту внаслідок формування умов, які зроблять стан миру економічно вигідним для різних верств населення. Охарактеризовані неформальні інститути, які є невід 'ємною частиною постконфліктної економіки, та описані рішення і дії, які дають змогу нівелювати вплив таких інститутів на суспільні відносини через різні форми спонукання населення до переведення своєї діяльності у легальну площину. Наведені управлінські практики, які можуть створити подальші передумови для сталого розвитку постконфліктних територій з урахуванням феномену «постконфліктного зростання» індивідів.

Надано характеристику ризикам, які можуть виникати перед акторами політичного проиесу, та описано можливі шляхи їх подолання. Розглянуто міжнародну технічну допомогу як важливий інструмент для відновлення постконфліктної економіки. Проаналізовано переваги та недоліки процесів, пов 'язаних із отриманням міжнародної технічної допомоги, зокрема, ризик втручання донорів, які надають допомогу, в процеси управління. Запропоновано моделі для запобігання такому вручанню.

Ключові слова: політика управління постконфліктними територіями, постконфліктна економіка, примирення.

Постановка проблеми. В управлінні постконфліктними територіями спеціальна економічна політика як комплекс економічних завдань та заходів може стати дієвим інструментом для досягнення примирення в суспільстві. При розв'язанні конфлікту економічні чинники зазвичай не визнаються сторонами як ключові причини та передумови конфлікту. Втім, актори політичного конфлікту у своєму протистоянні здебільшого спираються на маргінальні соціальні групи, які виникають внаслідок невдоволення учасників таких груп своїм економічним становищем. Саме тому, при виробленні управлінських практик економічної політики постконфліктна влада має орієнтуватися на психологічний стан індивідів - членів постконфліктного суспільства, враховувати вплив попередніх економічних практик періоду конфлікту та ризики, які випливають із особливостей постконфліктного періоду як унікального феномену в міжнародній практиці.

Мета статті. Через дослідження та характеристику управлінських практик у сфері економічної політики автор має на меті довести тезу про те, що формування умов для здійснення економічної діяльності як окремого індивіда, так і суспільства в цілому, може сприяти примиренню та зниженню рівня конфліктогенності постконфліктної території.

Аналіз актуальних досліджень. Дослідження політики управління постконфліктними територіями як комплексу спеціальних управлінських практик здійснювалося вітчизняними науковцями А. Кice, I. Мединським, К. Зарембо. Серед зарубіжних дослідників політики управління постконфліктними територіями варто виділити комплексні дослідження В. Четейла, П. Колієра, Ч. Гегнона, М. Фішера. Специфічні риси економіки на постконфліктних територіях досліджувалися К. Койном, Т. Коуеном, Г. Брауном. Спеціальні методи антикризового управління в економіці досліджувалися російськими вченими В. Горбовим, Ю. Гаджиєвим, І. Кіслухіною, В. Лексиним, а 
також зарубіжними науковцями А. Каркозьким та В.Бейкером. До економічних управлінських практик на конкретних постконфліктних територіях зверталися зарубіжні науковці Л. Вікс та Д. Бутбі. Вітчизняні науковці Ю Макагон, Ю. Харазішвілі, В. Ляшенко аналізують стан економічних відносин внаслідок військового конфлікту на окупованих територіях Донецької та Луганської областей.

Виклад основного матеріалу. Умови, в яких актори постконфліктної політики здійснюють свою діяльність, характеризуються низкою особливостей, які мають бути враховані при формуванні управлінських практик у сфері економіки для подальшого примирення постконфліктного суспільства та сталого розвитку постконфліктних територій.

Примирення через економіку. Основи для доведення можливості досягнення примирення в суспільстві через економіку були закладені ще в моделі економічної людини Адама Сміта. За версією Адама Сміта, індивід у житті має основною метою поліпшення свого становища для досягнення влади в суспільстві. Також Адам Сміт звертає увагу на так звану «схильність людини до обміну». В господарській діяльності людина керується власним егоїзмом, тому комунікація між людьми, які мають від такої комунікації спільну вигоду, дозволяє набагато краще узгодити інтереси сторін [1, с.15-20].

Подальші дослідження в рамках теорії раціонального вибору розвинули цю тезу. Теоретики раціонального вибору стверджували, що індивід, який приймає раціональні рішення, вступає у відносини обміну із іншими раціональними індивідами для досягнення власної вигоди [2].

Конкретне питання постконфліктного примирення через економічні відносини було винесено на порядок денний наукових досліджень у сфері економіки та політичної науки у кінці 20 століття. Спираючись на запропоновані вище теорії та моделі, а також на низку інших економічних концепцій, К. Койн робить висновок про те, що фокусування на економічному способі мислення для політика в управлінні постконфліктними територіями може опосередковано сформувати примирювальні наративи, необхідні постконфліктному суспільству. 3 точки зору політичної економії, реконструкцію та процес примирення можна розглядати як проблему сумісності та суперечності стимулів. Стимули є центральним поняттям поведінкової економіки та посилаються на фактори, які впливають на напрям людської поведінки. Основним припущенням про економічний спосіб мислення є те, що реакція людей на стимули обумовлена їх цілеспрямованою поведінкою. У контексті стимулів ті, хто керує реконструкцією та процесом примирення, мають встановити такі «правила гри», що створюють позитивний стимул для громадян використовувати, поважати та інвестувати в постконфліктні інститути - політичні, економічні та соціальні - в довгостроковій перспективі [3, с.69-73]. Інакше кажучи, економіка дає змогу використовувати фактори та механізми, які створюють стимули для співпраці на противагу стимулів для конфлікту.

Перш за все, стимулювання індивідів до примирення у постконфліктний період може здійснюватися через сприяння у налагодженні економічних відносин між представниками сторін, що були у конфронтації в період конфлікту. В постконфліктних реаліях рівень упередження сторін не нівелюється миттєво. Спеціалісти у сфері політичної психології зазначають, що схильність до співробітництва індивідів після конфлікту носить доволі специфічний характер. 3 одного боку, внаслідок конфлікту індивід втрачає довіру до оточуючих. 3 іншого боку - виникає потреба у розбудові нових соціальних зв’язків для досягнення власного добробуту [5]. Тому постконфліктна влада може здійснити диверсифікацію соціальних страт з метою мобілізації активів індивідів навколо нових економічних можливостей. Зокрема, такий механізм було застосовано у Руанді, де влада запропонувала представникам різних етносів долучитися до фермерських кооперативів з видобутку кавових зерен [6]; у Косово, де представники Корпусу миру цілеспрямовано організовували економічні форуми та конференції для налагодження торгівлі між різними етносами [5, с.72]; у Хорватії, де поряд із колишньою лінією розмежування було організовано ринок та майданчик для спілкування [7].

По-друге, для створення в індивідів стимулів до примирення постконфліктна влада має здійснювати діяльність, спрямовану на забезпечення зайнятості. Населення, яке буде залучене у процеси постконфлікного відновлення та отримуватиме від такого відновлення певні економічні преференції, вже не матиме зацікавленості у поверненні до стану конфлікту, адже волітиме зберегти власне економічне становище та набуті доходи. Для забезпечення зайнятості населення можуть бути здійснені наступні управлінські дії:

1. У постконфліктний період важливим є забезпечення зайнятості дорослих чоловіків, більшість iз яких тим чи іншим чином були втягнені у конфлікт. Дослідники постконфліктних територій 
зазначають, що найбільш ефективним виходом із такої ситуації буде створення робочих місць у сфері відновлення інфраструктури;

2. Звертаючись до політичної психології, конфлікт та постконфліктний період створюють передумови до так званого посттравматичного зростання. Окрім поглиблення стосунків з оточенням в рамках нових соціальних груп, індивід відчуває схильність до саморозвитку. Після тривалого травмування люди вже не хочуть просто мати роботу, заробляти гроші. Для них стає важливим виявляти і розвивати власні здібності, робити те, що подобається, до чого є природна схильність [5];

3. Фокусування на місцевих ресурсах у процесі відбудови постконфліктної території так само сприятиме зайнятості населення цих територій. Маються на увазі, зокрема, заходи зі стимулювання місцевого виробництва. Так, у Мапуту, столиці постконфліктного Мозамбіку, було прийнято рішення будувати вторинні дороги в місті з використанням бетонного мощення, а не асфальту. Будівництво асфальтних доріг потребувало б залучення закордонних спеціалістів. В свою чергу, дороги 3 бетону можливо будувати 3 цементу та піску, які добувалися безпосередньо в країні $[4$, с. 58$]$.

Неформальні економічні інститути. Війна викликає значні зміни в структурі економіки. Окрім руйнації стабільної економічної системи важливий вплив на економіку в часи конфлікту справляють неформальні економічні відносини, обумовлені відсутністю належного нормативного регулювання. Тут мається на увазі незаконний обіг зброї та наркотиків, контрабанда, крадіжки тощо. Втім, економіка ніколи не зникає взагалі, навіть у період затяжних конфліктів [4, с. 37].

Британський економіст П. Мюрел звертає увагу на економічну політику у перехідні періоди. Зокрема, досліджуючи перехідний період від комунізму та капіталізму, П. Мюрел визначає, що однією $з$ ключових проблем перехідного періоду є нехтування попереднім досвідом економічного розвитку, особливо його неформальних аспектів [8]. На нашу думку, ці висновки можуть бути поширені на постконфліктний період - при розробленні економічної політики для постконфліктної території важливо ретельно проаналізувати та враховувати, зокрема, неформальні економічні відносини, що склалися в період конфлікту.

Для прикладу можуть бути наведені наступні неформальні економічні відносини та заходи щодо їх формалізації та/або знищення:

Регулювання обігу зброї. Діяльність з відновлення владного контрою над обігом зброї включена у постконфліктній політиці до комплексу заходів під спільною назвою РДР (роззброєння, демобілізація та реінтеграція). Зазвичай цей комплекс заходів відносять до реформування сектору безпеки, втім у процесі регулювання обігу зброї виникає економічний контекст. Вирішення проблеми значної кількості зброї на руках як у комбатантів, так і у цивільного населення вимагає нестандартних дій. Так, в міжнародній практиці існує дві форми роззброєння - примусове та добровільне. Саме добровільна форма роззброєння має на меті застосування механізму економічних стимулів для індивіда.

Добровільне роззброєння може здійснюватися різними акторами 3 використанням різних методів. Так, зокрема, проекти Програми розвитку ООН включали обмін зброї на мікро-кредити, інструменти та техніку (Камбоджа, Нікарагуа, Мозамбік) [9]. Цікавим для дослідження є також приклад програми викупу зброї у Хорватії. Перехідна адміністрація ООН для Східної Славонії, Баранії і Західного Срієму ініціювала програму викупу зброї на умовах анонімності. Було досягнуто згоди із хорватським національним урядом про фінансування цієї програми за їх рахунок. Частина викупленої зброї була контрольовано знищена. Інша частина зберігалася під наглядом Перехідної адміністрації, а після закінчення іiі мандату була передана для використання хорватській владі. Таким чином, за рахунок цієї програми вдалося не тільки знизити кількість зброї на руках у населення, алей підсилити оборонний потенціал національних збройних сил та правоохоронних органів [10].

Неформальна торгівля. Визнання проблеми неформальних ринкових відносин та спроба взяти їх під контроль - важливий елемент в постконфліктній економічній політиці. У цій сфері доволі ефективними вбачаються спроби формалізувати такі відносини та вивести їх у національну правову площину. Втім, недопустимим для постконфліктного управління буде будь-яка формалізація або потурання практикам, які мають ознаки кримінально караної діяльності. Звичайно, такі практики виникають та функціонують у конфліктному суспільстві, а подолати їх у постконфліктний період стає можливим тільки 3 використанням сили. Так, після встановлення управління Перехідної адміністрації ООН у Хорватії парамілітарне угрупування «Скорпіон» (з частин збройних угрупувань так званої Республіки Сербська Країна) захопило нафтове родовище Джелетовці та продовжувало 
його контролювати у перехідний період, поставляючи нафту звичними каналами на території сусідньої Сербії. Для отримання контрою над цим нафтовим родовищем згодом Перехідною адміністрацією була розроблена збройна операція з використанням військової компоненти місії [11].

Підтримка закордонних та міжнародних фінансових структур. На постконфліктні економіки світу з часів закінчення Другої світової війни значний вплив має фінансова допомога міжнародної спільноти. Зважаючи на те, що на сьогодні навіть внутрішньодержавні конфлікти визнаються проблемою глобального масштабу, постконфліктна влада має високі шанси долучити до процесів управління територіями та їх відновлення значні фінансові ресурси.

Звичайно, на етапі становлення постконфліктної економіки фінансова допомога міжнародних фінансових структур в значній частині забезпечує підтримку економіки. Донори безповоротно інвестують у відновлення пошкодженої інфраструктури та базових соціальних послуг. Донори реалізують проекти та програми, які дають змогу створювати нові робочі місця. Для національної влади важливо створити та забезпечити нормальні умови роботи таких міжнародних фінансових структур як унікальних інвесторів. Це може проявлятися у пільгах по сплаті певних податків та зборів, спрощеній процедурі реєстрації та/або легалізації тощо.

Незважаючи на таку важливість і результативність донорських програм у сучасному світі, співпраця із міжнародними фінансовими структурами має свої ризики. По-перше, існує загроза втручання з боку донорів у процеси управління. На сьогодні усі найбільш грунтовні аналітичні дослідження постконфліктного управління належать міжнародним організаціям. Навіть цей факт засвідчує те, що такі організації не тільки надають підтримку постконфліктним процесам, а ще й намагаються впливати на формування нового політико-правового порядку на постконфліктних територіях.

Завчасне налагодження взаємодії із міжнародними фінансовими структурами може бути вирішенням цієї проблеми. Так, спеціалісти Програми розвитку ООН у своєму звіті про економіку постконфліктних територій радять урядам створювати цільові фонди багатьох партнерів. 3 позиції самих донорів - їм зручніше працювати в форматі подібних фондів [12]. А для національного уряду започаткування такого фонду дозволить здійснювати загальну координацію над процесами фінансування та інвестування у постконфліктну економіку через єдиний центр управління.

У контексті ризиків роботи із безповоротною фінансовою допомогою варто звернути увагу на ще одну проблему. Хоча міжнародна технічна допомога на постконфліктній території створює необхідні передумови для подальшого економічного розвитку, вона також може спровокувати залежність від неї. Певні паралелі в цьому випадку можуть бути проведені із концепцією «самаритянської дилеми» Дж.М. Б'юкенена, який досліджував проблему надання матеріальної підтримки населенню соціальними державами. Дж.М. Б'юкненен стверджував, що, надаючи необгрунтовану фінансову підтримку населенню, соціальна держава руйнує мотивацію такого населення на власний заробіток, створюючи передумови залежності від допомоги [13]. Так само, для донорів, які надають фінансову та ресурсну допомогу постконфліктним територіям, важливо залишити в національних та регіональних органів постконфліктної влади стимули для самостійного розвитку. Саме тому зважене та збалансоване фінансування проектів та програм на постконфліктних територіях - спільна відповідальність таких міжнародних фінансових структур і національних органів управління. Тому, по-перше, проекти, що впроваджуються за підтримки міжнародної технічної допомоги, мають виходити на сталість та самоокупність, а по-друге, потрібно розглядати можливості отримання доходу з цих територій або ж залучення інвестицій з боку комерційних структур, які будуть зацікавлені у розвитку регіону.

Висновки та перспективи подальших досліджень. Характеристика економічного стану постконфліктної території дозволяє підтвердити висновок про те, що для досягнення сталого миру існуватиме необхідність впровадження спеціальної економічної політики. Зокрема, при розробленні рішень та дій постконфліктного управління пропонується враховувати психологічні якості «постконфліктного індивіда» - його потенціал до постконфліктного зростання та формування нових соціальних груп, а також його раціональність як економічної людини.

Важливою для постконфліктної політики також буде стратегія поводження і неформальними економічними інститутами, які матимуть кримінальні ознаки. Люди, які відчували на собі вплив конфлікту, за його період здійснили певну адаптацію до існуючих політичних та економічних реалій 3 метою власного виживання. Частину 3 неформальних інститутів, які складаються у період конфлікту, необхідно рішуче руйнувати. Формалізація ж іншої частини може вимагати від влади здійснення нестандартних дій у співпраці із населенням. 
Окремо автором було зауважено на ризиках співпраці із міжнародними фінансовими структурами. Залучення донорів на постконфліктні території у перший час формує сприятливий економічний клімат, створює робочі місця та певним чином сприяє легітимізації постконфліктної влади. Втім, існують ризики виникнення залежності від безповоротної допомоги. Для запобігання таким ризикам автором було наголошено на необхідності для національного уряду зайняти рішучу позицію координатора донорських програм у співробітництві із міжнародними фінансовими структурами.

Подальшими дослідженнями автор планує виявляти управлінські практики у різних сферах політичного та соціального життя на постконфліктній території та оцінювати їх ефективність 3 метою грунтовної характеристики політики управління постконфліктними територіями як цілісної моделі.

\section{Бібліографічний список:}

1. Чаплыгина И.Г. «Экономический человек» Дж.С.Милл и Адама Смита: методологический аспект. // Научные исследования экономического факультета. Электронный журнал. [Електроний ресурс] - С. 15-20. Режим доступу - https://archive.econ.msu.ru/sys/raw.php?o=3642\&p=attachment

2. Швери Рольф Теория раціонального выбора: аналитический обор [Електронний ресурс] - Режим доступу до ресурсу: http://jour.isras.ru/upload/journals/1/articles/161/submission/original/161-301-1-SM.pdf.

3. Coyne C. J. Reconstruction and Reconciliation: What's Economics Got to Do With It? // The Whitehead Journal of Diplomacy and International Relations. - 2017. - pp. 69-83.

4. Post-Conflict Economic recovery Enabling Local Ingenuity [Електронний ресурс] - Режим доступу до ресурсу: http://www.undp.org/content/dam/undp/library/crisis\%20prevention/undp-cpr-post-conflict-economicrecovery-enable-local-ingenuity-report-2008.pdf

5. Титаренко Т.М. Особистість перед викликами війни: психологічні наслідки травматизації // Проблеми політичної психології. - 2017. - Випуск 5 (19). - С. 3-9.

6. Wicks L. Rwanda 's Miracle: From Genocide and Poverty to Peace and Economic Prosperity [Електронний pecypc] / Laura Wicks // Florida International University FIU Digital Commons. - 2014. - Режим доступу до ресурсу: http://digitalcommons.fiu.edu/cgi/viewcontent.cgi?article=2614\&context=etd

7. United Nations Transitional Authority in EasternSlavonia, Baranja and Western Sirmium: archived web-site [Електронний ресурс] - Режим доступу до ресурсу: https://peacekeeping.un.org/mission/past/untaes.htm.

8. Murell P. The Transition According to Cambridge, Mass.. // Journal of Economic Literature. - 1995 . № 33. - pp. 164-178.

9. Disarmament, Demobilization, Reinsertion \& Reintegration: Actors \& Activities [Електронний ресурс] Режим доступу до pecypcy: http://www.peacebuildinginitiative.org/index631d.html?pageId=1820\#the-differentways-of-administering-disarmament.

10. Boothby D. The UNTAES Experience: Weapons buy-back in Eastern Slavonia, Baranja and Western Sirmium / Derek Boothby // Bonn International Centre for Conversion. - 1998. - Brief 12. - p.37.

11. Boothby D. The Political Challenges of Administering Eastern Slavonia / Derek Boothby // Global Governance. - 2004. - Vol. 10, No. 1 - 2004. - pp. 37-51.

12. Україна Оцінка відновлення та розбудови миру Аналіз впливу кризи та потреб на східній Україні [Електронний ресурс] - Режим доступу до ресурсу: http://www.un.org.ua/images/RPA_V1_Ukr.pdf

13. Schmidtchen D. To Help or not to Help: The Samaritan's Dilemma Revisited. // CSLE Discussion Paper. 1999. - pp. 1-14.

\section{Mykhalska V. V. Post-conflict management practices in the economic policy}

Specific features, connected with the influence of past conflict, characterize economic situation in the post-conflict area. It is these features that make it possible to characterize post-conflict management as a separate political and legal category. These specificities should determine the activities of actors to achieve the goal of post-conflict policy.

The article defines the characteristics of post-conflict social relations, examines the problems of the functioning of the post-conflict economy, and presents concrete management practices - examples from various post-conflict countries of the world - that solve these problems. The economic recovery of post-conflict areas is considered from the point of view of the psychological state and needs of individuals living in such territories. It is revealed that decisions and actions in the economic policy oriented on the individual can contribute to the achievement of reconciliation in society and prevent return to the state of conflict because of the formation of conditions that will make peace more economically profitable for different segments of the population. The informal institutions that are an integral part of the post-conflict economy are described, and the decisions and actions are showed that make it possible to level the influence of such institutes on social relations through various forms of motivating 
the population to transfer their activities to the legal plane. Management practices are presented that can create further prerequisites for the sustainable development of post-conflict areas, taking into account the phenomenon of "post-conflict growth" of individuals.

The description of the risks that may arise before the actors of the political process is given, and the possible ways of overcoming them are described. International technical assistance is considered as an important tool for the recovery of the post-conflict economy. The advantages and disadvantages of processes related to obtaining international technical assistance are analyzed, in particular, the risk of donors' interventions in management processes. Models are proposed for preventing such an interventions.

Key words: post-conflict management policy, post-conflict economy, reconciliation. 